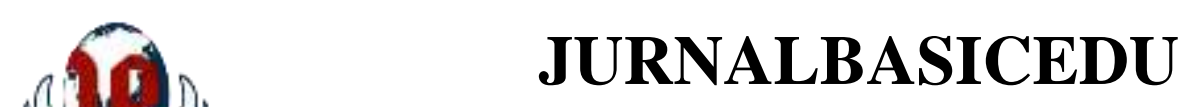

Volume 5 Nomor 6 Tahun 2021 Halaman 5370 - 5378

Research \&Learningin Elementary Education https://jbasic.org/index.php/basicedu

\title{
Analisis Kebutuhan Perangkat Pembelajaran Model PjBL Terintegrasi STEM Berbasis E- Learning di Masa Pandemi Covid-19
}

\author{
Roudhoutul Aulia Rochim ${ }^{1}$, Prabowo², Mohammad Budiyanto ${ }^{3}$ \\ Universitas Negeri Surabaya, Indonesia ${ }^{1,2,3}$ \\ E-mail: roudhoutul.20001@mhs.unesa.ac.id
}

\begin{abstract}
Abstrak
Pembelajaran di sekolah mengalami perubahan dari pembelajaran konvensional (tatap muka) menjadi pembelajaran daring, mengikuti protokol kesehatan physical distancing yang dianjurkan oleh pemerintah. Keefektifan pembelajaran dimulai dari perencanaan yang tentunya menggunakan prosedur dan konsep yang baik. Studi pendahuluan menunjukkan bahwa masih kurangnya pengembangan perangkat pembelajaran . Project based learning (PjBL) merupakan model pembelajaran yang mengajarkan konsep melalui sebuah proyek yang berpusat pada siswa. STEM sebagai pendekatan yang dapat mengintegrasikan pengetahuan, teknologi, teknik, dan matematika serta rancangan implementasi dengan model PjBL untuk meningkatkan pemahaman konsep siswa. Tujuan penelitian ini adalah menganalisis kebutuhan pengembangan perangkat pembelajaran model PjBL terintegrasi STEM berbasis e-learning pada materi tekanan. Jenis penelitian yang digunakan adalah penelitian deskriptif dengan teknik kuesioner terbuka dan tertutup. Hasil penelitian yang didapatkan bahwa guru membutuhkan perangkat pembelajaran yang baik dan menambah pemahaman konsep siswa.
\end{abstract}

Kata Kunci: Analisis Kebutuhan Perangkat Pembelajaran, PjBL terintegrasi STEM berbasis e-learning, Tekanan, Pemahaman Konsep.

\begin{abstract}
Learning in schools has changed from conventional learning (face to face) to online learning, following the physical distancing health protocol recommended by the government. The effectiveness of learning starts from planning which of course uses good procedures and concepts. Preliminary studies show that there is still a lack of development of learning tools. Project based learning (PjBL) is a learning model that teaches concepts through a student-centered project. STEM is an approach that can integrate knowledge, technology, engineering, and mathematics as well as implementation design with PjBL models to improve students' conceptual understanding. The purpose of this study was to analyze the need for developing a STEM-based integrated PjBL model of learning tools based on e-learning on the subject of pressure. The type of research used is descriptive research with open and closed questionnaire techniques. The results obtained that teachers need good learning tools and increase students' understanding of concepts.
\end{abstract}

Keywords: Learning Materials Needs Analysis, STEM-integrated PjBL based on e-learning, Pressure, Concept Understanding

Copyright (c) 2021 Roudhoutul Aulia Rochim, Prabowo, Mohammad Budiyanto

Corresponding author :

Email : roudhoutul.20001@mhs.unesa.ac.id

DOI $\quad$ : https://doi.org/10.31004/basicedu.v5i6.1655

ISSN 2580-3735 (Media Cetak)

ISSN 2580-1147 (Media Online) 


\section{PENDAHULUAN}

Pandemi Covid-19 menjadikan dunia pendidikan mengalami keterlambatan proses untuk kemajuan. Seluruh elemen kehidupan manusia di bumi terganggu, tanpa kecuali pendidikan. Kementerian Pendidikan dan Kebudayaan Direktorat Pendidikan Tinggi mengeluarkan surat edaran nomor 1 Tahun 2020 tentang pelaksanaan kebijakan pendidikan dalam masa darurat penyebaran Coronavirus Disease (Covid-19) yaitu pembelajaran jarak jauh. Kebijakan ini menuntut pendidik dan siswa beradaptasi terhadap pembelajaran daring berbasis e-learning melalui jaringan internet di rumah masing-masing.

Berdasarkan hasil wawancara dengan beberapa guru ketika peneliti mengikuti pelatihan IGI Jombang, diperoleh informasi bahwa di beberapa sekolah guru menyatakan bahwa perangkat yang mereka gunakan hanya mencontoh perangkat pembelajaran yang ada di internet ataupun yang sudah jadi dalam bentuk file. Guru merasa kesulitan untuk mengembangkan pembelajaran berbasis e-learning dan dalam kegiatan belajar kurang bervariasi dalam menggunakan model pembelajaran. Model pembelajaran yang memberikan kesempatan bagi siswa dan membantu siswa mendapatkan pemahaman tentang metode ilmiah guna mengembangkan kemampuan pemahaman konsep, pengaturan diri, dan pemahaman tentang topik-topik spesifik adalah model pembelajaran project based learning (PJBL) Annisa et al., (2018); Chung et al., (2020).

Pembelajaran PJBL memberi kesempatan pada siswa belajar melalui pengalaman atau perolehan konsep yang dibangun berdasarkan produk akhir yang dihasilkan dalam belajar. Produk yang dihasilkan dapat berupa ide/gagasan atau pun perangkat yang dapat dilihat. Hal ini siswa memperoleh pemahamannya melalui pertanyaan-pertanyaan yang dapat menjawab rasa penasaran mereka Fernandes, (2014); Parrado-Martínez \& Sánchez-Andújar, (2020). Produk yang dikembangkan salah satunya diintegrasi melalui Science, Technology, Engineering, and Mathematics (STEM).

STEM merupakan sebuah pendekatan interdisipliner antara sains, teknologi, teknik dan matematika, didalamnya terdapat empat aspek yang memiliki kesesuaian terhadap pembelajaran berbasis masalah sehingga menciptakan pembelajaran yang aktif dan menyatukan konsep yang abstrak dari setiap aspek Force, (2014); Siahaan et al., (2021). Pembelajaran berintegrasi STEM melibatkan keterampilan yang berbeda-beda diantaranya membaca, menulis, matematis, dan membangun konsep pengetahuan Erdoğan et al., (2016); Hanif et al., (2019). Kurikulum 2013 merupakan kurikulum yang dapat disesuaikan dengan pendekatan pembelajaran STEM Gustiani et al., (2017);Wang \& Degol, (2017). Dengan diterapkannya pendekatan STEM ini diharapkan peserta didik mempunyai keahlian belajar dan berinovasi yang meliputi berpikir kritis, kreatif, inovatif, serta mampu berkomunikasi dan berkolaborasi (Juniaty et al., 2016). PJBL berintegrasi STEM merupakan pembelajaran kontekstual seperti bereksplorasi, merencanakan aktivitas belajar, melaksanakan proyek secara kolaboratif, dan pada akhirnya menghasilkan suatu hasil produk Jauhariyyah et al., (2017);Craft \& Capraro, (2017), Penerapan karakteristik STEM pada kurikulum nasional akan lebih maksimal dan dapat memotivasi guru sehingga memberikan dampak positif bagi kegiatan dan hasil pembelajaran (Murnawianto et al., 2017).

Pada mata pelajaran IPA dipelajari berbagai hal termasuk materi tekanan. Pada materi tekanan hidrostatis, peserta didik harus menguasai konsep bahwa di dalam zat cair semakin besar kedalaman maka tekanannya juga semakin besar (Rahmawati et al., 2016). Tekanan yang semakin ke bawah semakin besar tidak terlihat sehingga perlu divisualisasikan, sehingga siswa ksesulita dalam memahami konsep yang ingin coba diraih. Seperti dikemukakan Devi dalam (Astuti et al., 2019). Salah satu bentuk visualisasi tersebut dengan melakukan kegiatan pembelajaran proyek, mengungkapkan bahwa STEM mampu meningkatkan keterampilan belajar dan berinovasi, memecahkan masalah, menemukan/ merancang hal baru, memahami diri, melakukan pemikiran logis dan menguasai teknologi.

Adapun kesesuaian materi Tekanan dalam model pembelajaran project based learning didasarkan atas beberapa pertimbanagan. Pertama, materi Tekanan membutuhkan penalaran dan pemahaman konsep yang 
lebih sehingga mendorong siswa untuk belajar secara aktif dan kolaboratif, tepatnya menerapkan pembelajaran berpusat pada siswa. Kedua, materi Tekanan sulit sehingga membutuhkan sejumlah masalah yang mampu memotivasi, mengembangkan kreativitas dan potensi yang ada dalam diri siswa baik pengetahuan, sikap dan keterampilan serta mendorong siswa berhadapan dengan konsep-konsep dan prinsipprinsip pokok pengetahuan secara langsung sebagai pengalaman tangan pertama. Salah satu itu dapat dicapai dengan menerapkan model pembelajaran project based learning.

Pengembangan perangkat pembelajaran PjBL terintegrasi STEM dalam pembelajaran IPA, diharapkan dapat membantu kegiatan belajar mengajar menjadi lebih efektif dan diharapkan siswa bisa dilatih untuk memahami konsep. Bahan ajar secara langsung mempengaruhi pembelajaran yang akan diberikan oleh guru. Sehingga pemilihan bahan ajar pun sangat penting. Terdapat bukti yang kuat bahwa pemilihan bahan ajar lebih berdampak pada belajar siswa dibandingkan dengan efektivitas guru (Chingos \& Whitehurst, 2012). .

Produk yang dihasilkan dari penggunaan PjBL dapat menjadi kontribusi siswa terhadap peningkatan kualitas kehidupan. Siswa dapat membuat produk dengan memanfaatkan IPTEK sehingga siswa secara tidak langsung memahami fungsi dan manfaat IPTEK itu sendiri terhadap kebaikan untuk lingkungan. Begitupun juga pengintegrasian STEM dalam perangkat pembelajaran menjadi lebih bermakna Lutfi et al., (2018);Afriana et al., (2016), sehingga penting untuk melaksanakan pembelajaran dengan bahan ajar yang dapat secara efektif mencapai tujuan pembelajaran, pemilihan STEM sudah tepat dalam pelaksanaan penelitian ini. Tujuan dari penelitian ini untuk menganalisis kebutuhan perangkat pembelajaran model pembelajaran PjBL terintegrasi STEM pada materi Tekanan berbasis e-learning.

\section{METODE PENELITIAN}

Jenis penelitian kualitatif dan kuantitatif yang digunakan untuk memberikan fakta, realita (Sugiyono, 2016), gejala dan peristiwa alamiah yang diperoleh secara akurat sugiyono dalam Nurhidayat \& Asikin, (2021). Studi ini menggunakan dua objek yang diteliti. Objek pertama yakni Guru IPA di suatu sekolah untuk mendapatkan informasi mengenai penerapan pembelajaran pada materi IPA. Terdapat 20 guru IPA dari beberapa guru di Provinsi Jawa Timur. Sampel ini diambil secara acak karena sebagai sampel yang mewakili guru dan siswa yang ada di Jawa Timur. Objek kedua yakni siswa yang terlibat dalam pengumpulan informasi ini berjumlah 28 siswa.

Teknik pengumpulan data dalam penelitian ini menggunakan kuesioner tertutup dan kuesioner terbuka. Kuesioner yang digunakan mengenai masalah dalam pelaksanaan pembelajaran IPA oleh guru dan siswa. Instrumen yang digunakan berupa pertanyaan jawaban penjelasan dan pertanyaan jawaban pilihan ganda. Teknik analisis data yang digunakan dalam penelitian ini adalah analisis statistik deskriptif. Statistik deskriptif dapat digunakan untuk mendeskripsikan objek yang diteliti melalui data sampel atau populasi sebagaimana adanya. Statistik deskriptif ini tanpa melakukan analisis dan membuat kesimpulan yang berlaku untuk umum Sudijono, dalam Adlim \& Mursal, (2015).

\section{HASIL DAN PEMBAHASAN}

Pengembangan perangkat pembelajaran IPA model PjBL terintegrasi STEM bertujuan untuk menuntun siswa mengaitkan konsep pembelajaran ke dunia nyata. Peneliti dalam penelitian mengembangkan perangkat pembelajaran yang disesuaikan dengan kondisi lingkungan agar kegiatan belajar mengajar dapat terlaksana dengan optimal tanpa terhalang jarak dan waktu dan tercapainya tujuan salah satunya kemampuan pemahaman konsep. 
5373 Analisis Kebutuhan Perangkat Pembelajaran Model PjBL Terintegrasi STEM Berbasis E-Learning di Masa Pandemi Covid-19 - Roudhoutul Aulia Rochim, Prabowo, Mohammad Budiyanto

DOI: https://doi.org/10.31004/basicedu.v5i6.1655

\section{Hasil Kuesioner Terbuka}

Berdasarkan pertanyaan dari kuesioner terbuka oleh guru dan siswa didapatkan jawaban terkait kebutuhan bahan ajar pada materi Tekanan sebagai berikut. Hasil tersebut dapat dilihat ada Tabel 1 dan Tabel 2 .

Tabel 1. Hasil Kuesioner Terbuka Analisis Kebutuhan Perangkat Pembelajaran Model PjBL Terintegrasi STEM oleh Guru

\begin{tabular}{|c|c|c|}
\hline No & Pertanyaan & Hasil Jawaban \\
\hline 1. & $\begin{array}{l}\text { Bagaimana strategi pembelajaran yang } \\
\text { diterapkan pada pembelajaran IPA? }\end{array}$ & $\begin{array}{l}\text { Strategi pembelajaran yang selama ini digunakan } \\
\text { oleh } 13 \text { guru responden antara lain inkuiri, } \\
\text { kooperatif, diskusi, ceramah, demonstrasi } \\
\text { eksperimen, latihan soal dan tanya jawab. }\end{array}$ \\
\hline 2. & $\begin{array}{l}\text { Apa sajakah bahan belajar yang telah } \\
\text { digunakan pada materi IPA? }\end{array}$ & $\begin{array}{l}\text { Bahan ajar yang selama ini digunakan meliputi: } \\
\text { a. Buku teks } \\
\text { b. Video pembelajaran } \\
\text { c. Modul } \\
\text { d. Power point } \\
\text { e. LKS } \\
\text { f. Laboran } \\
\text { g. Artikel dan internet }\end{array}$ \\
\hline 3. & $\begin{array}{l}\text { Bagaimana pendapat Bapak/Ibu Guru tentang } \\
\text { penerapan STEM yang diintegrasikan ke } \\
\text { dalam perangkat pembelajaran? }\end{array}$ & $\begin{array}{l}\text { Semua responden memberikan tanggapan positif } \\
\text { yaitu dapat mengembangkan konsep yang } \\
\text { dimiliki siswa. }\end{array}$ \\
\hline 4. & $\begin{array}{l}\text { Bagaimana pendapat Bapak/lbu Guru jika } \\
\text { dalam materi Tekanan dikembangkan } \\
\text { perangkat pembelajaran model PjBL } \\
\text { terintegrasi STEM? }\end{array}$ & $\begin{array}{l}\text { Semua responden menjawab dengan respon yang } \\
\text { baik karena dapat mendukung keterlibatan siswa } \\
\text { aktif dan inovatif. }\end{array}$ \\
\hline 5. & $\begin{array}{l}\text { Menurut pendapat Bapak/Ibu Guru, apakah } \\
\text { dengan dikembangkan perangkat } \\
\text { pembelajaran PjBL terintegrasi STEM pada } \\
\text { materi Tekanan dapat menambah wawasan } \\
\text { pemahaman konsep siswa? }\end{array}$ & $\begin{array}{l}\text { Semua responden memberikan jawaban dapat } \\
\text { menambah wawasan dan pemahaman konsep } \\
\text { siswa. }\end{array}$ \\
\hline
\end{tabular}

Tabel 2. Hasil Kuesioner Terbuka Analisis Kebutuhan Perangkat Pembelajaran Model PjBL Terintegrasi STEM oleh Siswa

\begin{tabular}{cll}
\hline No & \multicolumn{1}{c}{ Pertanyaan } & \multicolumn{1}{c}{ Hasil Jawaban } \\
\hline 1. & $\begin{array}{l}\text { Sumber belajar apa sajakah yang saudara gunakan untuk } \\
\text { pembelajaran IPA? }\end{array}$ & $\begin{array}{l}\text { Rata-rata jawaban siswa terkait sumber } \\
\text { belajar yang digunakan buku, LKS, } \\
\text { youtube, internet, dan aplikasi belajar } \\
\text { online. }\end{array}$ \\
\hline $2 . \quad \begin{array}{l}\text { Bagaimana strategi belajar yang diterapkan pada } \\
\text { pembelajaran IPA? }\end{array}$ & $\begin{array}{l}\text { Strategi pembelajaran yang selama ini } \\
\text { digunakan berbasis latihan soal, } \\
\text { praktikum, dan belajar mandiri. }\end{array}$ \\
\hline 3. & $\begin{array}{l}\text { Materi IPA manakah yang saudara anggap sulit di kelas } \\
\text { VIII? }\end{array}$ & $\begin{array}{l}\text { Sejumlah 8 responden mengatakan } \\
\text { materi tekanan sulit. }\end{array}$ \\
\hline $4 . \quad \begin{array}{l}\text { Apakah pembelajaran daring untuk pembelajaran IPA di } \\
\text { sekolah selama ini secara efektif? }\end{array}$ & $\begin{array}{l}\text { Sejumlah 10 responden mengatakan } \\
\text { pembelajaran daring untuk } \\
\text { pembelajaran IPA di sekolah selama } \\
\text { ini belum efektif. }\end{array}$ \\
& $\begin{array}{l}\text { Bagaimana pendapat saudara jika materi Tekanan } \\
\text { dikembangkan perangkat pembelajaran model PjBL }\end{array}$ & $\begin{array}{l}\text { Semua responden mengatakan setuju } \\
\text { jika materi Tekanan dikembangkan }\end{array}$ \\
\hline
\end{tabular}


5374 Analisis Kebutuhan Perangkat Pembelajaran Model PjBL Terintegrasi STEM Berbasis E-Learning di Masa Pandemi Covid-19 - Roudhoutul Aulia Rochim, Prabowo, Mohammad Budiyanto

DOI: https://doi.org/10.31004/basicedu.v5i6.1655

\begin{tabular}{cll}
\hline No & Pertanyaan & \multicolumn{1}{c}{ Hasil Jawaban } \\
\hline & terintegrasi STEM? & $\begin{array}{l}\text { perangkat pembelajaran model PjBL } \\
\text { terintegrasi STEM }\end{array}$ \\
\hline
\end{tabular}

Berdasarkan tabel 1 pada pertanyaan 1 dan 2 didapatkan hasil berupa pandangan guru sebagai responden mengenai kebutuhan pengembangan perangkat pembelajaran model PjBL terintegrasi STEM pada materi Tekanan. Didapatkan data bahwa terdapat kesulitan siswa dalam memahami rumus dan dalam hal perhitungan prinsip tekanan. Hal tersebut terjadi dikarenakan penguasaan konsep siswa kurang. Hal tersebut juga dikemukakan oleh Jannatu et al., (2015);Islami et al., (2020), pembelajaran PjBL terintegrasi STEM tidak hanya sekedar memberikan pengetahuan kepada siswa namun juga menjadikan pengetahuan itu lebih bermakna melalui kegiatan proyek yang dapat mengubah konsep yang bersifat abstrak menjadi nyata, sehingga konsep tersebut dapat diingat dalam jangka panjang oleh siswa ((Lukman et al., 2015).

Pada poin 3 dan 4 didapatkan hasil bahwa strategi pembelajaran yang digunakan oleh guru antara lain inkuiri, kooperatif, diskusi, ceramah, demonstrasi eksperimen, latihan soal dan tanya jawab. Bahan ajar yang digunakan berupa buku teks, laboran, gambar, LKS, modul, power point, video pembelajaran, laboran, artikel dan internet. Strategi dan bahan ajar yang digunakan untuk mendorong siswa terlibat langsung dalam kegiatan belajar. Hal ini sesuai dengan pernyataan Agustina et al., (2020) menunjukkan perbedaan kemampuan berpikir ilmiah peserta didik yang diajarkan dengan menggunakan pembelajaran STEM terintegrasi dan STEM silo pada materi reproduksi tumbuhan dan hewan di kelas IX SMP. Dengan menggunakan STEM yang terintegrasi dalam PjBL maka siswa dapat secara efektif memahami materi pelajaran dengan baik.

Pada poin 5 didapatkan hasil bahwa STEM yang diintegrasikan ke dalam perangkat pembelajaran sangat membantu siswa dalam proses belajar mengajar. Peintegrasian STEM dalam pembelajaran mampu meningkatkan pemahaman konsep. Salah satunya pada langkah model PjBL terintegrasi STEM yakni pada fase research. Pada tahap research menuntut siswa mengumpulkan infromasi yang relevan berdasarkan proyek yang akan dibuat. Siswa dituntut memahami konsep-konsep relevan berdasarkan proyek yang dikerjakan. Hal ini mengindikasikan bahwa siswa diberikan ruang dalam mengeksplorasi kemampuannya untuk menggali informasi yang bertujuan mengembangakan pemahaman konsep yang dimiliki (Lutfi et al., 2018).

Berdasarkan tabel 2 didapatkan hasil terkait kebutuhan strategi pembelajaran dari perspektif siswa bahwa sumber belajar selama ini menggunakan buku, majalah/koran, sesama teman, dan internet. Strategi dan pendekatan pembelajaran masih dalam bentuk latihan soal, praktikum, dan belajar mandiri. Salah satu responden mengatakan bahwa pembelajaran belum terintegrasi dengan pendekatan tertentu, selain itu responden juga mengatakan diperlukan pengembangan perangkat pembelajaran terintegrasi STEM pada materi tekanan dikarenakan cakupan materi tersebut luas. Hasil temuan tersebut diperkuat oleh Astuti et al., (2019)mengungkapkan bahwa banyak model pembelajaran yang dapat digunakan untuk pendekatan STEM dalam pembelajaran IPA. Diantara model tersebut model PjBL menggunakan platform e-learning menjadi salah satu solusi di tengah pandemik Covid-19 untuk mengoptimalkan pembelajaran sehingga pengetahuan dan ilmu yang didapatkan siswa dapat menjadi bekal dalam kehidupan sehari-hari (Saputra \& Sujarwanta, 2021).

\section{Hasil Kuesioner Tertutup}

Berdasarkan pertanyaan dan kuesioner tertutup oleh guru dan siswa diperoleh jawaban terkait kebutuhan perangkat pembelajaran model PjBL terintegrasi STEM pada materi Tekanan pada gambar 1. 


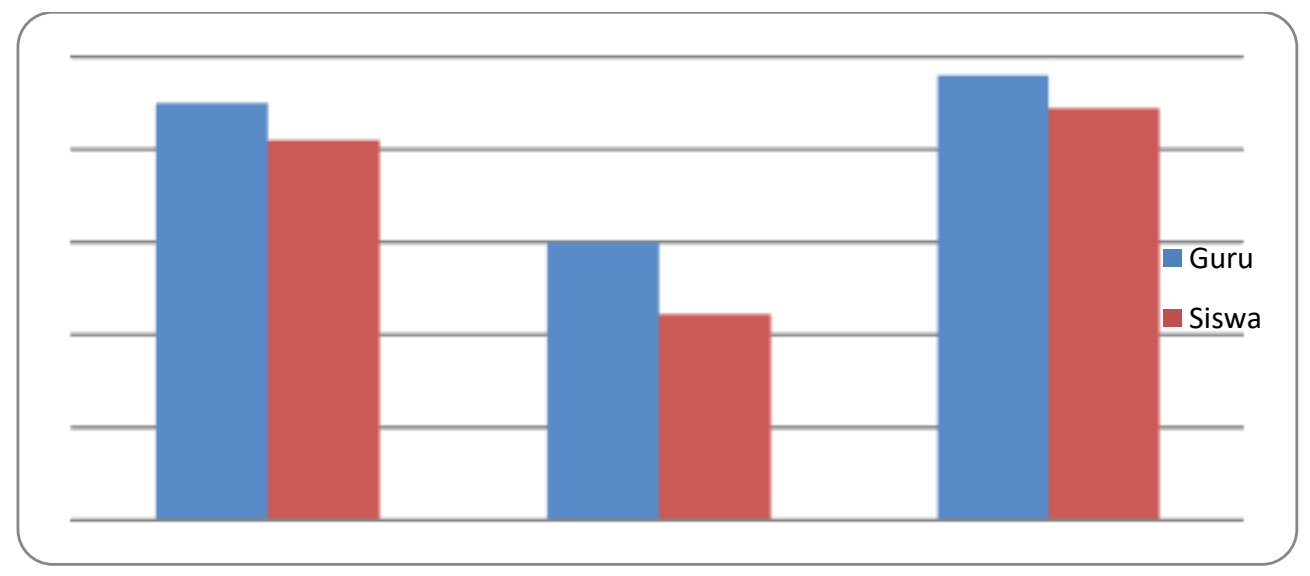

\section{Gambar 1. Hasil Kuesioner Tertutup Analisis Kebutuhan Perangkat Pembelajaran Model PjBL Terintegrasi STEM}

Pada penelitian ini, hasil penelitian mengacu kepada kategori analisis kebutuhan dengan ketentuan apabila nilai diperoleh $88<\mathrm{N} \leq 100$ dikategorikan sangat bagus, untuk nilai $76<\mathrm{N} \leq 88$ dikategorikan baik, untuk nilai $65<\mathrm{N} \leq 76$ dikategorikan cukup dan nilai $<65$ dikategorikan kurang. Berdasarkan hasil penelitian pada Tabel 3, hasil analisis guru dan siswa diperoleh bahwa tingkat kepercayaan mengintegrasikan STEM menggunakan model pembelajaran $\mathrm{PjBL}$ berada pada kategori sangat bagus, sedangkan tingkat keterlaksanaan pembelajaran daring untuk pembelajaran IPA di sekolah secara efektif selama ini dikategorikan kurang. Hal ini dikarenakan siswa hanya diberikan tugas dari guru namun tidak dibimbing. Hasil analisis pada tingkat kepercayaan terhadap perangkat pembelajaran model PjBL terintegrasi STEM berbasis e-learning pada materi Tekanan dikategorikan sangat bagus, dalam hal ini kepercayaan responden untuk meningkatkan proses pembelajaran PjBL terintegrasi STEM berbasis e-learning perlu dilakukan.

Hasil penelitian ini menjadi acuan dalam mengembangkan perangkat pembelajaran dengan model pembelajaran yang mendukung proses pembelajaran IPA di kelas, yakni model PjBL terintegrasi STEM berbasis e-learning. Tingkat kepercayaan guru dan siswa terhadap pembelajaran IPA pada materi Tekanan dengan menggunakan model PjBL terintegrasi STEM berbasis e-learning sebesar 88,9 dan 96, oleh karena itu diperlukan pengembangan perangkat model PJbL terintegrasi STEM yang disesuaikan dengan kebutuhan siswa. Perangkat pembelajaran menjadi hal penting untuk menyusun rencana, tujuan, dan materi yang akan dilaksanakan, dicapai, dan diberikan dalam pembelajaran. Perangkat pembelajaran dapat membantu guru untuk menyiapkan kelas lebih baik dan mengevaluasi pemahaman dan kemampuan siswa secara menyeluruh.

Solusi ini didukung oleh penelitian yang dilakukan oleh (Wijayanto et al., 2020)dalam penelitian tersebut Wijayanto melakukan pembelajaran Fisika menggunakan model project based learning dengan pendekatan STEM pada pokok bahasan vektor, dari penelitian tersebut disimpulkan bahwa model PjBL dengan pendekatan STEM siswa lebih memahami konsep materi yang diberikan karena siswa dapat terlibat secara langsung dalam penyusunan perancangan proyek dalam pemecahan masalah menggunakan konsep Fisika. Penelitian serupa juga ditulis oleh (Astuti et al., 2019) mengenai model pembelajaran PjBL terintegrasi STEM sangat tepat diterapkan dalam pembelajaran dikarenakan mampu berpengaruh terhadap interaksi siswa dengan lingkungannya. Kelebihan dari model pembelajaran tersebut dapat meningkatkan aktivitas belajar siswa dikarenakan siswa dituntut aktif menyelesaikan suatu proyek dan diterapkan dalam kehidupan seharihari.

Pada model PjBL terintegrasi STEM siswa mampu memahami konsep dengan membuat produk, dan pada pembelajaran STEM terjadi proses perancangan dan redesign (engineering design process) sehingga membuat siswa menghasilkan produk terbaiknya. Integrasi aspek-aspek STEM memberikan dampak positif terhadap proses belajar mengajar terutama dalam hal peningkatan hasil belajar siswa di bidang sains dan 
teknologi (Becker \& Park, 2011), penelitian dengan menggunakan bahan ajar fisika dengan model STEMPjBL (Science, Technology, Engineering, Mathematics and Project-based Learning) yang terintegrasi dengan TPACK (Technological Pedagogical Content Knowledge) sangat valid, praktis, dan efektif secara statistik untuk meningkatkan keterampilan pemecahan masalah siswa (Purwaningsih et al., 2020) serta Modul berbasis STEM ini juga dapat memotivasi siswa dalam mempelajari materi IPA (Zulaiha \& Kusuma, 2020). Hal tersebut mendukung hasil penelitian ini yang menyatakan perangkat pembelajaran model PjBL terintregrasi STEM pada materi Tekanan memiliki kriteria sangat bagus dan juga mendukung pembelajaran yang menggunakan perangkat pembelajaran berbasis e-learning, serta menjadikan siswa mudah dalam memahami materi Tekanan, sebagai materi yang dirasakan sulit untuk dipahami oleh sebagian besar siswa. Untuk penelitian yang akan datang sebaiknya dapat menerapakan model pembelajaran STEM pada materi-materi di luar materi tekanan, dengan harapan bisa menjadi khazanah efektifitas pembelajaran.

\section{KESIMPULAN}

Pengembangan perangkat pembelajaran PjBL terintegrasi STEM pada materi Tekanan dapat ditemukan hasil analisis kuesioner tertutup dan terbuka. Analisis ini memuat kebutuhan guru dan siswa dengan hasil identifikasi bahwa guru dan siswa di beberapa sekolah di Jawa Timur sangat setuju dengan pengembangan perangkat pembelajaran PjBL terintegrasi STEM pada materi Tekanan. Hasil penelitian yang didapatkan bahwa guru membutuhkan perangkat pembelajaran yang baik dan menambah pemahaman konsep siswa. Model pembelajaran yang diinginkan siswa adalah menggunakan PjBL terintegrasi STEM. Pembelajaran PjBL terintegrasi STEM efektif dilakukan di masa pandemi Covid-19 secara daring dengan memberikan proyek kepada siswa yang melibatkan sains, teknologi, teknik, dan matematika. Tingkat kepercayaan guru dan siswa terhadap perangkat pembelajaran model pembelajaran PJBL terintegrasi STEM pada materi Tekanan sebesar 88,96 dan 96. Oleh karena itu, diperlukan pengembangan perangkat perangkat model PjBL terintegrasi STEM berbasis e-learning.

\section{DAFTAR PUSTAKA}

Adlim, A., \& Mursal, M. (2015). Pengembangan Lks Stem (Science, Technology, Engineering, And Mathematics) Dalam Meningkatkan Motivasi Dan Aktivitas Belajar Siswa Sma Negeri 1 Beutong Pada Materi Induksi Elektromagnetik. Jurnal Pendidikan Sains Indonesia, 3(1), 239-250.

Afriana, J., Permanasari, A., \& Fitriani, A. (2016). Project Based Learning Integrated To Stem To Enhance Elementary School's Students Scientific Literacy. Jurnal Pendidikan Ipa Indonesia, 5(2), 261-267.

Agustina, R., Huda, I., \& Nurmaliah, C. (2020). Implementasi Pembelajaran Stem Pada Materi Sistem Reproduksi Tumbuhan Dan Hewan Terhadap Kemampuan Berpikir Ilmiah Peserta Didik Smp. Jurnal Pendidikan Sains Indonesia (Indonesian Journal Of Science Education), 8(2), 241-256.

Annisa, R., Effendi, M. H., \& Damris, M. (2018). Peningkatan Kemampuan Berpikir Kreatif Siswa Dengan Menggunakan Model Project Based Learning Berbasis Steam (Science, Technology, Engineering, Arts Dan Mathematic) Pada Materi Asam Dan Basa Di Sman 11 Kota Jambi. Journal Of The Indonesian Society Of Integrated Chemistry, 10(2), 42-46.

Astuti, I. D., Toto, T., \& Yulisma, L. (2019). Model Project Based Learning (Pjbl) Terintegrasi Stem Untuk Meningkatkan Penguasaan Konsep Dan Aktivitas Belajar Siswa. Quagga: Jurnal Pendidikan Dan Biologi, 11(2), 93-98.

Becker, K. H., \& Park, K. (2011). Integrative Approaches Among Science, Technology, Engineering, And Mathematics (Stem) Subjects On Students' Learning: A Meta-Analysis.

Chingos, M. M., \& Whitehurst, G. J. (2012). Choosing Blindly: Instructional Materials, Teacher 

Masa Pandemi Covid-19 - Roudhoutul Aulia Rochim, Prabowo, Mohammad Budiyanto DOI: https://doi.org/10.31004/basicedu.v5i6.1655

Effectiveness, And The Common Core. Brookings Institution.

Chung, C.-C., Huang, S.-L., Cheng, Y.-M., \& Lou, S.-J. (2020). Using An Isteam Project-Based Learning Model For Technology Senior High School Students: Design, Development, And Evaluation. International Journal Of Technology And Design Education, 1-37.

Craft, A. M., \& Capraro, R. M. (2017). Science, Technology, Engineering, And Mathematics Project-Based Learning: Merging Rigor And Relevance To Increase Student Engagement. Electronic International Journal Of Education, Arts, And Science (Eijeas), 3(6).

Erdoğan, N., Navruz, B., Younes, R., \& Capraro, R. M. (2016). Viewing How Stem Project-Based Learning Influences Students' Science Achievement Through The Implementation Lens: A Latent Growth Modeling.

Fernandes, S. R. G. (2014). Preparing Graduates For Professional Practice: Findings From A Case Study Of Project-Based Learning (Pbl). Procedia-Social And Behavioral Sciences, 139, 219-226.

Force, S. T. (2014). Innovate: A Blueprint For Science, Technology, Engineering, And Mathematics In California Public Education. Dublin, Ca: Californians Dedicated To Education Foundation.

Gustiani, I., Widodo, A., \& Suwarma, I. R. (2017). Development And Validation Of Science, Technology, Engineering And Mathematics (Stem) Based Instructional Material. Aip Conference Proceedings, $1848(1), 60001$.

Hanif, S., Wijaya, A. F. C., \& Winarno, N. (2019). Enhancing Students' Creativity Through Stem ProjectBased Learning. Journal Of Science Learning, 2(2), 50-57.

Islami, S., Yanto, D. T. P., \& Candra, O. (2020). Validitas Jobsheet Instalasi Perumahan Berbasis Proyek Berbantuan E-Learning Di Pendidikan Vokasi. Intecoms: Journal Of Information Technology And Computer Science, 3(2), 174-178.

Jannatu, N., Supartono, S., \& Wardani, S. (2015). Penerapan Pembelajaran Berbasis Proyek Berbantuan ELearning Untuk Meningkatkan Hasil Belajar Siswa. Jurnal Inovasi Pendidikan Kimia, 9(2).

Jauhariyyah, F. R., Suwono, H., \& Ibrohim, I. (2017). Science, Technology, Engineering And Mathematics Project Based Learning (Stem-Pjbl) Pada Pembelajaran Sains. Seminar Nasional Pendidikan Ipa 2017, 2.

Juniaty, W., Zubaidah, S., \& Supriyono, K. H. (2016). Steam: Apa, Mengapa, Dan Bagaimana. Prosiding. Pros Semnas Pend Ipa Pascasarjanaum, 1(1), 976-984.

Lukman, L. A., Martini, K. S., \& Utami, B. (2015). Efektivitas Metode Pembelajaran Project Based Learning (Pjbl) Disertai Media Mind Mapping Terhadap Prestasi Belajar Siswa Pada Materi Pokok Sistem Koloid Di Kelas Xi Ipa Sma Al Islam 1 Surakarta Tahun Ajaran 2013/2014. Jurnal Pendidikan Kimia, 4(1), 113-119.

Lutfi, L., Azis, A. A., \& Ismail, I. (2018). Pengaruh Project Based Learning Terintegrasi Stem Terhadap Literasi Sains, Kreativitas Dan Hasil Belajar Peserta Didik. Seminar Nasional Biologi.

Murnawianto, S., Sarwanto, S., \& Rahardjo, S. B. (2017). Stem-Based Science Learning In Junior High School: Potency For Training Students' Thinking Skill. Pancaran Pendidikan, 6(4).

Nurhidayat, M. F., \& Asikin, M. (2021). Bahan Ajar Berbasis Stem Dalam Pembelajaran Matematika: Potensi Dan Metode Pengembangan. Prisma, Prosiding Seminar Nasional Matematika, 4, 298-302.

Parrado-Martínez, P., \& Sánchez-Andújar, S. (2020). Development Of Competences In Postgraduate Studies Of Finance: A Project-Based Learning (Pbl) Case Study. International Review Of Economics Education, 35,100192 .

Purwaningsih, E., Sari, A. M., Yuliati, L., Masjkur, K., Kurniawan, B. R., \& Zahiri, M. A. (2020). Improving The Problem-Solving Skills Through The Development Of Teaching Materials With Stem-Pjbl (Science, Technology, Engineering, And Mathematics-Project Based Learning) Model Integrated With Tpack 
5378 Analisis Kebutuhan Perangkat Pembelajaran Model PjBL Terintegrasi STEM Berbasis E-Learning di Masa Pandemi Covid-19 - Roudhoutul Aulia Rochim, Prabowo, Mohammad Budiyanto

DOI: https://doi.org/10.31004/basicedu.v5i6.1655

(Technological Pedagogical Content Knowledge). Journal Of Physics: Conference Series, 1481(1), 12133.

Rahmawati, I., Hidayat, A., \& Rahayu, S. (2016). Peguasaan Konsep Ipa Siswa Smp Pada Materi Tekanan Pada Zat Cair Dan Aplikasinya. Jurnal Pendidikan Sains, 4(3), 102-112.

Saputra, B., \& Sujarwanta, A. (2021). Transformasi Pembelajaran Berbasis Proyek Science, Technology, Engineering And Mathematics Di Masa Pandemi Covid-19. Biolova, 2(1), 1-8.

Siahaan, K. W. A., Lumbangaol, S. T. P., Marbun, J., Nainggolan, A. D., Ritonga, J. M., \& Barus, D. P. (2021). Pengaruh Model Pembelajaran Inkuiri Terbimbing Dengan Multi Representasi Terhadap Keterampilan Proses Sains Dan Penguasaan Konsep Ipa. Jurnal Basicedu, 5(1), 195-205.

Sugiyono, H. (2016). Metode Kualitatif Dan Kuantitatif. Cetakan Ke-23. Alfabeta, Bandung.

Wang, M.-T., \& Degol, J. L. (2017). Gender Gap In Science, Technology, Engineering, And Mathematics (Stem): Current Knowledge, Implications For Practice, Policy, And Future Directions. Educational Psychology Review, 29(1), 119-140.

Wijayanto, T., Supriadi, B., \& Nuraini, L. (2020). Pengaruh Model Pembelajaran Project Based Learning Dengan Pendekatan Stem Terhadap Hasil Belajar Siswa Sma. Jurnal Pembelajaran Fisika, 9(3), 113120.

Zulaiha, F., \& Kusuma, D. (2020). Pengembangan Modul Berbasis Stem Untuk Siswa Smp. Jurnal Pendidikan Fisika Dan Teknologi, 6(2), 246-255. 